\title{
The Effects of Related Factors on One- and Two-Year Mortality after a Hip Fracture in Elderly Turkish Patients
}

\author{
Kalça Kırıkl Yaşlı Türk Hasta Grubunda Bir ve İki Yillık Mortaliteyi Etkileyen Faktörler
}

\author{
Tolga ATAY, ${ }^{2}$ Berit GÖKÇE CEYLAN, ${ }^{3}$ Ahmet ÖZMERIÇ, ${ }^{2}$ Füsun EROĞLU, ${ }^{3}$ Lütfi YAVUZ, ${ }^{3}$ \\ Nurettin HEYBELİ, ${ }^{1}$ Metin Lütfi BAYDAR ${ }^{2}$
}

${ }^{1}$ Department of Orthopedics and Traumatology, Medical Faculty of Trakya University, Edirne; Departments of ${ }^{2}$ Orthopedics and Traumatology and ${ }^{3}$ Anesthesiology and Reanimation, Medical Faculty of Süleyman Demirel University, Isparta

Submitted / Başvuru tarihi: 12.10.2008 Accepted / Kabul tarihi: 19.11.2008

\begin{abstract}
Objectives: Hip fractures are one of the most serious causes of impairment and death in the elderly. The aim of this study is to identify the effects of different risk factors on mortality after a hip fracture in elderly Turkish patients.
\end{abstract}

Patients and Methods: Two-hundred forty patients $(>60$ years; mean age $76.0 \pm 8.2$ years) who were operated for fracture of the hip from 2001 to 2006 were investigated. Demographic data, preoperative length of hospital stay, anesthesia type and ASA physical status, albumin level at admission and comorbidities were recorded.

Results: Mean albumin level was $3.45 \pm 0.62 \mathrm{~g} / \mathrm{dl}$. Onehundred eight $(45 \%)$ had hypoalbuminemia. The difference between mortality rates of normo- and hypoalbuminemic patients were not significant at one and two-year. According to preoperative length of stay; one-year mortality was significantly higher in male patients $(p=0.015)$ while two-year mortality was not. One-year mortality was related with high ASA physical status scores $(p=0.002)$ while two-year mortality was not $(p=0.169)$. According to gender; one-year mortality was found higher in men $(p=0.001)$.

Conclusion: Due to comorbidities, high ASA scores are common in elderly patients. Since the preoperative evaluation in high ASA physical status is longer, this may prolong the preoperative hospital stay. Delay after admission and high ASA physical status are important predictors of mortality for elderly hip fracture patients.

Key words: Hip fracture; mortality; ASA; albumin.
Amaç: Kalça kırıkları ileri yaşların fonksiyon kaybı ve ölüm ile sonuçlanabilen ciddi sağlık sorunlarındandır. Bu çalışmada amaç kalça kırığı sonrası yaşı Türk hastalarda değişik risk faktörlerinin mortalite üzerine etkisini ortaya koymaktır.

Hastalar ve Yöntemler: 2001-2006 yılları arasında kalça kırığı nedeniyle ameliyat edilmiş, 60 yaş ve üzeri, en az iki yıllık takibi olan 240 hastanın (ort. yaş $76.0 \pm 8.2$ ) demografik verileri, ameliyat öncesi süreleri, anestezi ve ASA fiziksel durumu, başvuru albumin düzeyi ile ek morbiditeleri incelendi.

Bulgular: Geliş albumin seviyesi $3.45 \pm 0.62 \mathrm{~g} / \mathrm{dl}$ olarak bulundu. Yüz sekiz hastada (\%45) albumin düşüklüğü vardı. Albumin düzeyine göre bir ve iki yıl mortalite oranı anlamlı değildi. Ameliyat öncesi yatış süreleri incelendiğinde; birinci yıl mortalitesi erkek hastalarda istatistiksel anlamlı yüksek bulunurken $(p=0.015)$, ikinci yıl mortalitesi bulunmadı. ASA fiziksel skorları yüksek olan hastaların birinci yıl mortaliteleri ile korelasyonunun istatistiksel olarak anlamlı olduğu ( $p=0.002)$, ikinci yılda ise olmadığı $(p=0.169)$ saptandı. Cinsiyet incelendiğinde, birinci yıl mortalitesi erkekler için yüksek bulundu $(p=0.001)$.

Sonuç: Yüksek ASA skorlarına ek morbiditeler nedeniyle yaşı hastalarda sık karşılaşılmaktadır. Preoperatif hazırlık sürecinin ASA skoru yüksek olan hastalarda uzun olması nedeniyle ameliyat öncesi süre uzayabilmektedir. Kalça kırığı olan hastaların bir ve iki yıllık mortalite öngörüsünde ASA fiziksel durumu ve ameliyat öncesi gecikmenin önemli belirteçler olduğu görüşündeyiz.

Anahtar sözcükler: Kalça kırı̆̆ı; mortalite; ASA; albumin.

Correspondence (IIletişim adresi): Dr. Tolga Atay. Süleyman Demirel Üniversitesi Tıp Fakültesi Ortopedi ve Travmatoloji Anabilim Dalı, 32260 Isparta. Tel: 0246 - 2112323 Fax (Faks): 0246 - 2370240 e-mail (e-posta): ataytolga@gmail.com

() Trakya Üniversitesi Tıp Fakültesi Dergisi. Ekin Tıbbi Yayıncııı tarafından basılımışır. Her hakkı sakııır.

(c) Medical Journal of Trakya University. Published by Ekin Medical Publishing. All rights reserved. 
Hip fracture is a frequent injury in the elderly, and is associated with a high incidence of functional impairment, complications and mortality. ${ }^{[1]}$ The number of patients with hip fractures is increasing globally, and the patients presenting have longer life expectancy. ${ }^{[2,3]}$

There are several risk scores to estimate perioperative risk. A very commonly accepted one is the American Society of Anesthesiologists (ASA) Physical Status classification that is an appropriate global index to assess the physical status of surgical patients undergoing anesthesia. ${ }^{[4]}$ Serum albumin has an important role in assessing in-hospital health status. It is also a strong predictor of early and late mortality after hospital discharge. ${ }^{[5,6]}$

The aim of this study is to determine the effect of different risk factors and specifically to evaluate the relationship between albumin levels, preoperative length of stay, ASA Physical Status and anesthesia type on oneyear and two-year mortality in a group of hip-fractured elderly Turkish patients.

\section{PATIENTS AND METHODS}

\section{Patients}

The medical records of 240 patients who were older than 60 years and admitted to our University Hospital's Orthopedics and Traumatology Department because of a hip fracture between January 2001 and September 2006 were retrospectively reviewed. Data on age, sex, length of hospital stay and clinical information that consisted of physician-assigned co-morbidity were obtained. Clinical characteristics and the most common medical complications which might affect the clinical outcome such as coronary artery disease, diabetes mellitus, chronic obstructive lung disease, and hypertension were recorded.

Exclusion criteria included pathologic or bilateral hip fractures as well as presence of other acute disabilities such as multiple trauma. This study was approved by the Health Research Ethics Board of our institution.

\section{Operation and Anesthesia Type}

Patients were classified preoperatively by the ASA physical status. American Society of Anesthesiologists (ASA) adopted a five category physical status classification system in 1963 for assessing a patient before surgery. A sixth category was later added. These are:

1. ASA I: A normal healthy patient.

2. ASA II: A patient with mild systemic disease.

3. ASA III: A patient with severe systemic disease.

4. ASA IV: A patient with severe systemic disease that is a constant threat to life.

5. ASA V: A moribund patient who is not expected to survive with or without the operation.

6. ASA VI: A declared brain-dead patient whose organs are being removed for donor purposes.
If the surgery is an emergency, the physical status score is followed by " $\mathrm{E}$ " (for emergency).

Patients fasted overnight and were given diazepam $10 \mathrm{mg}$ intramuscularly for premedication $30 \mathrm{~min}$ before operation. In the operating room, $0.9 \%$ saline infusion at a rate of $10-15$ ml.kg-1 was started 15 min before operation and oxygen was administered to all patients via nasal catheters. Standard monitoring included an electrocardiogram, noninvasive blood pressure, and peripheric oxygen saturation measurement. After an intravenous fluid preloaded, general or regional anesthesia (spinal or epidural) was performed. All patients were operated with standard techniques, lateral approach with posterolateral incision.

\section{Albumin assessment}

Preoperative serum albumin was determined by an overnight fasting blood sample, collected within $24 \mathrm{~h}$ following admission with a diagnosis of a fractured hip.

\section{Outcomes}

The primary outcome of interest, mortality, was obtained from the electronic discharge records. We followed up the hospital discharge records and for the patients who did not admit to the hospital, phone calls were made in order to check their health status to verify and to determine one- and two-year mortality.

\section{Statistical Analysis}

The effect of anesthesia type on one- and two-year mortality was analyzed by non-parametric chi-square test which was also used in determining the effects of ASA on one- and two-year mortality along with Pearson's correlation test. The effects of spinal and general anesthesia on one- and two-year mortality were expressed by Cross tabs. Effects of preoperative and postoperative length of hospital stay on one- and two-year mortality and albumin level and age parameters were analyzed by Spearman's test.

Data were expressed as mean \pm SD unless stated otherwise. $\mathrm{P}<0.05$ was considered to be statistically significant.

\section{RESULTS}

Two-hundred forty eligible patients, older than 60 years of age were treated for a hip fracture in our department between 2001 and 2006. The baseline demographics of the study were shown in Table 1. Mean age for the series was $76.01 \pm 8.24$ years and there was not a difference between male and female patients. Total mortality ratio was $41 / 240(17.1 \%)$ in two years; 31 in the first year (12.9\%) and 10 in the second year (4.2\%). According to preoperative length of stay; one-year mortality was significantly higher in male patients $(\mathrm{p}=0.015)$ while two-year mortality was not. Pre-existing baseline comorbidities were listed in Table 2. Only "coronary artery 
Table 1. Demographics and clinical characteristics of patients $(n=240)$

\begin{tabular}{lccc}
\hline & Female & Male & $p$ \\
\hline Number of patients & 131 & 109 & $0.156^{* *}$ \\
Mean age (years) & $\begin{array}{c}75.76 \pm 8.00 \\
(99-60)\end{array}$ & $\begin{array}{c}76.31 \pm 8.54 \\
(102-61)\end{array}$ & $0.609^{*}$ \\
& & & \\
Type of Anesthesia & 58 & 53 & $0.501^{* *}$ \\
$\quad$ General & 62 & 45 & $0.348^{* *}$ \\
$\quad$ Spinal & 11 & 11 & $0.651^{* *}$ \\
$\quad$ Epidural & & & \\
Length of stay (days) & $5.88 \pm 4.02$ & $6.33 \pm 4.70$ & $0.422^{*}$ \\
$\quad$ Preoperative & $14.25 \pm 6.82$ & $13.21 \pm 7.47$ & $0.284^{*}$ \\
$\quad$ Postoperative & & & \\
Fracture side & 69 & 60 & $0.713^{* *}$ \\
$\quad$ Right hip & 62 & 49 & \\
Left hip & & & \\
Type of femur fracture & 63 & 49 & $0.628^{* *}$ \\
$\quad$ Neck & 56 & 51 & $0.531^{* *}$ \\
Intertrochanteric & 7 & 8 & $0.525^{* *}$ \\
Subtrochanteric & 1 & 5 & $0.152^{* *}$ \\
Subcapital & 10 & 21 & $<0.0001^{* *}$ \\
One-year mortality & 7 & 3 & $<0.0001^{* *}$ \\
Two-year mortality & & & \\
\hline
\end{tabular}

*Independent samples t-test; **Pearson's chi-square.

disease" was significantly higher in male patients compared to female patients $(\mathrm{p}=0.047)$.

One-year mortality rate was significantly higher in male patients while two-year mortality rate was significantly higher in female patients $(\mathrm{p}<0.0001)$. Onehundred eleven patients received general anesthesia, while 107 received spinal and 22 epidural. At one year, 18 patients from general anesthesia group died while four patients died at year two. For spinal anesthesia; 12 patients died at year one, while six patients died at year two. For epidural anesthesia; one patient died at year one, while no patients died at year two. When spinal and general anesthesia techniques were compared, the difference was not significant statistically. The statistical evaluation of the data can be found at Table 3.

Mean albumin level was $3.45 \pm 0.62 \mathrm{~g} / \mathrm{dl}$ at admission. Patients were regarded as hypoalbuminemic if their levels were less than $3.4 \mathrm{~g} / \mathrm{dl}$. When patients were analyzed according to their albumin levels, one-hundred and eight patients $(45 \%)$ had hypoalbuminemia. Detailed analysis for comparison between hypo- and
Table 2. Pre-existing baseline comorbidities

\begin{tabular}{lccc}
\hline Comorbidities & Female & Male & $p$ \\
\hline Diabetes mellitus & 34 & 22 & 0.174 \\
Hypertension & 67 & 40 & 0.006 \\
Coronary artery disease & 2 & 8 & 0.047 \\
Chronic obstructive & 8 & 18 & 0.255 \\
$\quad$ pulmonary disease & & & \\
Cerebro-vasculary accident & 5 & 2 & 0.364 \\
\hline
\end{tabular}

normoalbuminemic patients can be found in Table 4 . There was no difference for mortality rates between hypo- and normoalbuminemic patients with regard to the anesthetic type.

When the patients were analyzed according to the ASA scores; one-year mortality was related to higher ASA scores $(\mathrm{p}=0.002)$ while two-year mortality was not $(\mathrm{p}=0.169)$. According to gender, one-year mortality was significant only in male patients $(\mathrm{p}=0.001)$. We found that the effects of postoperative length of stay, age, albumin levels, sedimentation rate, hemoglobin, and C-reactive protein levels and white blood cell counts on mortality were statistically insignificant $(\mathrm{p}>0.05)$.

\section{DISCUSSION}

There have been a number of published reports describing the various factors associated with increased risk of mortality after a hip fracture. ${ }^{[7-9]}$ In this study, we found that longer preoperative length of stay in the hospital is associated with higher one-year mortality. Preoperative duration of stay at the hospital was found to be dependent on the ASA classification. Moreover, we found that all patients died within one year were in high ASA classification. Therefore, it can be concluded that patients' co-morbidities have grossly affected mortality.

Voney et al. ${ }^{[10]}$ pointed that ASA classification is a good predictor of hospital stay. However, Klotz et al. ${ }^{[11]}$ warned that some more parameters should be added, like the severity of operative procedure, symptoms of respiratory disease and malignancy as well as the ASA score in predicting morbidity. With regard to our exclusion criteria for malignancy and using standard operative technique, we can conclude that ASA score itself is a good predictor of postoperative mortality. Another significant finding was higher mortality rates for male patients in the first year after the operation, which has some grounds in the literature. For instance, a national survey in Netherlands in 2004, found out that postop-

Table 3. One- and two-year mortality according to anaesthesia types applied

\begin{tabular}{lcccc}
\hline & $\begin{array}{c}\text { General anesthesia } \\
(\mathrm{n}=111)\end{array}$ & $\begin{array}{c}\text { Spinal anesthesia } \\
(\mathrm{n}=107)\end{array}$ & $\begin{array}{c}\text { Epidural anesthesia } \\
(\mathrm{n}=22)\end{array}$ & $p$ \\
\hline One-year mortality & $18(16.22 \%)$ & $12(11.21 \%)$ & $1(4.54 \%)$ & 0.257 \\
Two-year mortality & $4(3.60 \%)$ & $6(5.60 \%)$ & $0(0 \%)$ & 0.449 \\
\hline
\end{tabular}


Table 4. Data of patients according to the serum albumin levels

\begin{tabular}{lccc}
\hline Albumin Level & $<3.4 \mathrm{~g} / \mathrm{dl}$ & $\geq 3.4 \mathrm{~g} / \mathrm{dl}$ & $p$ \\
\hline Number of patients & 108 & 132 & $0.301^{* *}$ \\
(Male/Female) & $(45 / 63)$ & $(64 / 68)$ & \\
Mean age & $76.38 \pm 8.10$ & $75.70 \pm 8.36$ & $0.523^{*}$ \\
Type of anesthesia & & & \\
$\quad$ General & 44 & 67 & $0.506^{* *}$ \\
$\quad$ Spinal & 54 & 53 & \\
$\quad$ Epidural & 10 & 12 & \\
One-year mortality & & & \\
$\quad$ General & $\mathrm{n}=7(15.90 \%)$ & $\mathrm{n}=11(16.41 \%)$ & $0.685^{* *}$ \\
$\quad$ Spinal & $\mathrm{n}=7(12.96 \%)$ & $\mathrm{n}=5(9.43 \%)$ & \\
$\quad$ Epidural & $\mathrm{n}=1(10.00 \%)$ & $\mathrm{n}=0(0 \%)$ & \\
Two-year mortality & & & \\
$\quad$ General & $\mathrm{n}=1(2.70 \%)$ & $\mathrm{n}=3(5.35 \%)$ & $0.746^{* *}$ \\
$\quad$ Spinal & $\mathrm{n}=3(6.38 \%)$ & $\mathrm{n}=3(6.25 \%)$ & \\
$\quad$ Epidural & $\mathrm{n}=0(0 \%)$ & $\mathrm{n}=0(0 \%)$ & \\
\hline
\end{tabular}

*Independent samples t-test; **Pearson's chi-square.

erative mortality for men aged 70 years or over was 1.5 times as high as for women of the same age group. ${ }^{[12]}$

Anesthesia for hip fracture most commonly involves either a general or a regional anesthetic. ${ }^{[13]}$ In our study, we found that anesthesia type had no effect on one- or two-year mortality. Since surgery for hip fracture is performed in elderly patients; it is not therefore surprising that a survival advantage in any anesthetic technique does not extend into long term. Dzupa et al. ${ }^{[14]}$ found that after spinal anesthesia, $26.6 \%$ of patients died within one year and after general anesthesia $26.7 \%$, showing no statistically significant difference supporting our results.

Low serum albumin level has been found as an important risk factor for hip fracture and prolonged hospital stay. IT is considered as a marker of poor health outcome in various medical conditions. However, it should not be considered as adversely affecting the rehabilitation of elderly hip fracture patients ${ }^{[15]}$ although a relationship between low albumin levels and poor functional outcome has been found in the elderly, lower albumin predicting a greater functional decline. ${ }^{[5]}$ In our study; we have found no association between albumin levels and mortality rates of hip fractured patients.

Mortality after a hip fracture in elderly patients is common. We found that our one-year mortality after hip fracture was $12.9 \%$. Older age and male sex were independently associated with a greater risk of mortality; otherwise, it seemed that the primary determinants of mortality risk were related to the burden and mix of comorbidities present at the time of hip fracture. Many previous studies have documented the independent association of older age with increased mortality. Previous data regarding the independent association of male sex and increased mortality has been somewhat conflicting. ${ }^{[16-19]}$ In this study, we believe our data provide some of the strongest evidence that male sex is an important and independent risk factor for mortality in the setting of hip fracture.

Perhaps the most noteworthy finding of this study is just how important the type and number of baseline comorbidities are as determinants of mortality in the hip fracture population, both first and second year. Previous studies have documented that comorbidities are independently associated with mortality. ${ }^{[20-22]}$ The primary determinants of mortality in this population seem to be older age, male sex, and the number, type, and mix of pre-existing baseline comorbidities. Given that in-hospital mortality rates could vary from $<1 \%$ to $>15 \%$ according to prefracture characteristics and comorbidities, any comparison of outcomes across different hospitals demands adequate and validated risk-adjustment tools.

Hip fracture surgery is associated with high postoperative mortality and poor functional results. High ASA scores are common in these patients related to age and baseline comorbidities. Related to these factors, anesthesia specialists desire to assess the patients widely in the preoperative period. This may cause unintended preoperative delay. We concluded that too much delay after admission is an important predictor of mortality within one- and two-year for elderly patients who have a fracture of the hip. Optimally, such patients should have the operation as soon as possible after admission to the hospital.

\section{REFERENCES}

1. Pioli G, Barone A, Giusti A, Oliveri M, Pizzonia M, Razzano $\mathrm{M}$, et al. Predictors of mortality after hip fracture: results from 1-year follow-up. Aging Clin Exp Res 2006;18:381-7.

2. Kannus P, Parkkari J, Sievänen H, Heinonen A, Vuori I, Järvinen M. Epidemiology of hip fractures. Bone 1996;18(1 Suppl):57S-63S.

3. Foss NB, Kehlet H. Mortality analysis in hip fracture patients: implications for design of future outcome trials. $\mathrm{Br}$ J Anaesth 2005;94:24-9.

4. Annitage P, Berry G. Analysis of variance test for deletion of variables. In: Statistical methods in medical research. 3rd ed. Oxford: Blackwell Science; 1995. p. 351-8.

5. Mizrahi EH, Fleissig Y, Arad M, Blumstein T, Adunsky A. Admission albumin levels and functional outcome of elderly hip fracture patients: is it that important? Aging Clin Exp Res 2007;19:284-9.

6. Hershkovitz A, Kalandariov Z, Hermush V, Weiss R, Brill S. Factors affecting short-term rehabilitation outcomes of disabled elderly patients with proximal hip fracture. Arch Phys Med Rehabil 2007;88:916-21.

7. Geiger F, Schreiner K, Schneider S, Pauschert R, Thomsen $M$. Proximal fracture of the femur in elderly patients. The influence of surgical care and patient characteristics on post-operative mortality. [Article in German] Orthopade 2006;35:651-7. [Abstract]

8. Kenzora JE, McCarthy RE, Lowell JD, Sledge CB. Hip fracture mortality. Relation to age, treatment, preoperative ill- 
ness, time of surgery, and complications. Clin Orthop Relat Res 1984;(186):45-56.

9. Lu-Yao GL, Baron JA, Barrett JA, Fisher ES. Treatment and survival among elderly Americans with hip fractures: a population-based study. Am J Public Health 1994;84:1287-91.

10. Voney G, Biro P, Roos M, Frielingsdorf B, Shafighi M, Wyss P. Interrelation of peri-operative morbidity and ASA class assignment in patients undergoing gynaecological surgery. Eur J Obstet Gynecol Reprod Biol 2007;132:220-5.

11. Klotz HP, Candinas D, Platz A, Horvàth A, Dindo D, Schlumpf R, et al. Preoperative risk assessment in elective general surgery. Br J Surg 1996;83:1788-91.

12. Saltzherr TP, Borghans HJ, Bakker RH, Go PM. Proximal femur fractures in the elderly in The Netherlands during the period 1991-2004: incidence, mortality, length of hospital stay and an estimate of the care capacity needed in the future. [Article in Dutch] Ned Tijdschr Geneeskd 2006;150:2599-604. [Abstract]

13. Urwin SC, Parker MJ, Griffiths R. General versus regional anaesthesia for hip fracture surgery: a meta-analysis of randomized trials. Br J Anaesth 2000;84:450-5.

14. Dzupa V, Bartonícek J, Skála-Rosenbaum J, Príkazský V. Mortality in patients with proximal femoral fractures during the first year after the injury. [Article in Czech] Acta Chir Orthop Traumatol Cech 2002;69:39-44. [Abstract]

15. Zanocchi M, Maero B, Maina P, Ponzetto M, Francisetti F, Giona E, et al. Factors predicting a prolonged hospital stay in elderly patients. [Article in Italian] Minerva Med 2002;93:135-43. [Abstract]

16. Ooms ME, Vlasman P, Lips P, Nauta J, Bouter LM, Valkenburg HA. The incidence of hip fractures in independent and institutionalized elderly people. Osteoporos Int 1994;4:6-10.

17. Grisso JA, Kelsey JL, O'Brien LA, Miles CG, Sidney S, Maislin G, et al. Risk factors for hip fracture in men. Hip Fracture Study Group. Am J Epidemiol 1997;145:786-93.

18. Cumming RG, Klineberg RJ. Case-control study of risk factors for hip fractures in the elderly. Am J Epidemiol 1994;139:493-503.

19. Holt G, Smith R, Duncan K, Hutchison JD, Gregori A. Gender differences in epidemiology and outcome after hip fracture: evidence from the Scottish Hip Fracture Audit. J Bone Joint Surg [Br] 2008;90:480-3.

20. Duh MS, Mody SH, Lefebvre P, Woodman RC, Buteau $S$, Piech CT. Anaemia and the risk of injurious falls in a community-dwelling elderly population. Drugs Aging 2008;25:325-34.

21. Sebestyén A, Boncz I, Tóth F, Péntek M, Nyárády J, Sándor J. Correlation between risk factors and mortality in elderly patients with femoral neck fracture with 5-year followup. [Article in Hungarian] Orv Hetil 2008;149:493-503. [Abstract]

22. Cauley JA, Lacroix AZ, Wu L, Horwitz M, Danielson ME, Bauer DC, et al. Serum 25-hydroxyvitamin D concentrations and risk for hip fractures. Ann Intern Med 2008;149:242-50. 